\title{
Critical Success Factors in Developing Collaborative Design-Build Project Team to Improve Project Performance
}

\author{
Afrizal Nursin ${ }^{1 *}$, Yusuf Latief ${ }^{1}$, and Ibrahim $^{1}$ \\ ${ }^{1}$ Civil Engineering Department, Faculty of Engineering, University of Indonesia, Depok, Indonesia
}

\begin{abstract}
To complete a construction project, it takes the cooperation and collaboration of stakeholder involved in construction projects to obtain optimum project performance. Problems that frequently occur in construction projects is the lack of cooperation, lack of trust, ineffective communication, lack of visualization of the planned buildings and different relationships between stakeholders that project performance is not optimal. To overcome these problems need to develop a model of collaboration between stakeholders in a construction project. The purpose of this research is to identify the critical success factors of the collaboration of design and build construction project team so that can understand the influence of collaboration model to collaboration performance with the geographic, professional, stakeholder, and ethnic cultural boundary spanners in design and build construction project in Indonesia. This research uses factor analysis and variable relation with Structural Equation Modeling (SEM) method. The results found that geographical and ethical boundaries are influencing collaborative performance significantly.
\end{abstract}

\section{Introduction}

Collaboration and partnerships between owners and others have formed a full field of inquiry over the last decade. Hu studied the performance improvement of collaborations in construction and said that active collaborative development among all stakeholders and project life cycles is critical to improving the performance of construction projects [1]. Collaboration is the approach between stakeholders to secure the best decisions and results about design and construction choices. Collaborative of design and planning will maximize positive iterations and reduce negative iterations [2].

The construction industry has faced problems with lack of cooperation and trust [3], ineffective communication [4], [5], lack of visualization of planned buildings [6] and conflicting relationships among stakeholders [7]. Previous research on construction collaborations has shown new forms of collaborative approaches, such as partnerships, creating common spaces in construction problem solving [8], communication [9], trust [3], commitment and transparency [10].

\footnotetext{
* Corresponding author: afrizalnursin@gmail.com
} 
The study of collaborations found three boundary spanners that influence the success of project team collaboration ie geographic, professional, and stakeholder [11].

In this research, the fourth critical success factor of collaborative design and build construction projects is the cultural boundary spanner. Discussion of cultural boundaries is essential for research where many of the problems of collaboration and cooperation of construction project teams are hampered due to cultural differences, whether corporate culture [12] or ethnic culture [13]. Erwin in his research explains the factors that can integrate ethnic cultures such as historical togetherness, external threats, leader agreement, homogeneity in socio-cultural relations, and the interdependence of stakeholders [14].

The purpose of this research is to identify the critical success factors of collaboration of design and build construction project team so that can understand the influence of collaboration model to collaboration performance with the geographic, professional, stakeholder, and ethnic cultural boundary spanners in design and build construction project in Indonesia

\section{Literature review}

\subsection{Collaboration}

Collaboration is an activity that involves many people with various interests to achieve mutually satisfying outcomes. Collaboration is known by many names, some popular names include "problem solving", "consensus", "desire-based negotiation", "win-win solution", "mutual benefit", and "principled negotiation" [15]. The purpose of the collaboration is to manage the dispute so that the result is more constructive than destructive. The results spawned effective communication, problem-solving, and improved relationships [16], [17]. Benefits and advantages of collaboration include: improving profits by sharing expertise among business units or companies; Practical cost reduction; Enhance decision-making through sharing deep insights; Innovation through sharing ideas; Improving the ability to pursue targets [18]. Owners control full collaboration through sharing information at the beginning of the project process most likely to achieve desired results: fast, efficient, effective, and related building costs. Owners must be the part that drives these changes, by leading the creation of collaboration, cross-functional teams composed of design, construction, and professional management facilities [19]. The process of collaboration consists of preparation, seeking consensus agreements, and after the final agreement of deliberation [20]. The collaborative strategy consists of bringing the parties together in collaboration, providing understanding, determining the desired level of success, explaining project collaboration, identifying possible barriers, identifying non-collaborative components, and collaborative commitment of members [20]. The leadership style of the collaboration consists of the leadership of organizational structure, important information leadership, leadership in decision-making authority, leadership by accountability and industry, and leadership in the best possible way [21]. The process of collaboration, strategy, leadership style, and collaboration models are the independent variables in this study (X). The performance of collaboration is the dependent variable in this study (Y).

\subsection{Collaboration Types / Models}

The collaboration types made the model of collaboration that consists of (1) the type of collaboration base on the process, then named as process collaboration [22], (2) the type of collaboration base on the task-dependent, named as task dependent collaboration model [23], (3) the type of collaboration that full of integration, then named full integration model [24], 
(4) consortium model [25], information democracy and multi-organizational project model [26]. The performance of collaboration is the dependent variable in this study (Y).

\subsection{Collaboration Performances}

Collaboration performance in this research gets the well know of the project team, get trust of the project team, good communication, encourage to contribute to solving problems, create a solid and well-connected project team, high flexibility space in the dynamics of project implementation, innovative methods of high innovation in the team drive [27], as well as a strong and passionate sharing of knowledge sharing contributes experience based on expertise, and there is an intercultural customization, the same feeling in the nation and language [14].

\section{Methodologies}

This research collected data questionnaires from 127 respondents who dabbled in building construction and infrastructure project used an object of this research. The instrument in this study consist of two variables, namely the dependent variable (collaboration performances) and independent variables (collaboration model and boundary spanners).

The instrument of data processing in this research consists of a questionnaire that will be used to analyze the influence of indicators and this relationship with SEM (Structural Equation Modeling) method. In this research will be conducted some analysis, consisting of statistical analysis of homogeneity test using SPSS, relationship analysis with SEM PLS, and analysis of inner model evaluation.

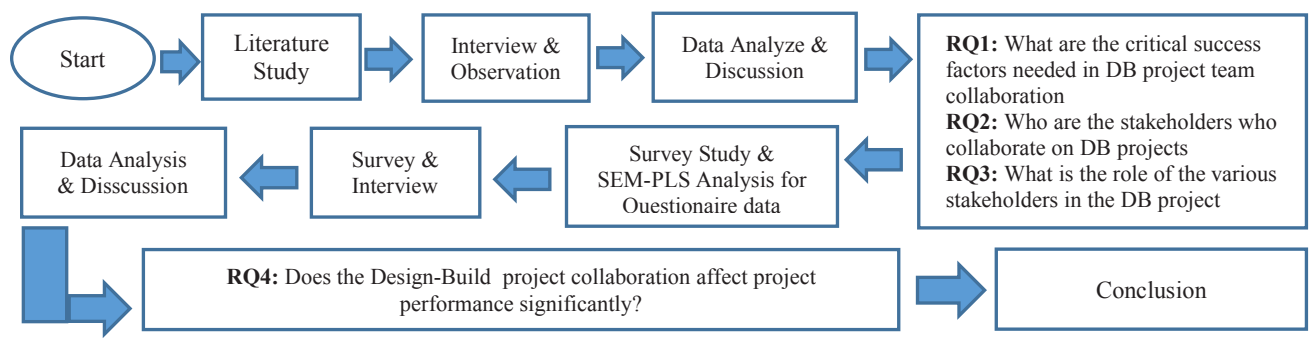

Fig. 1. Research Methodologies

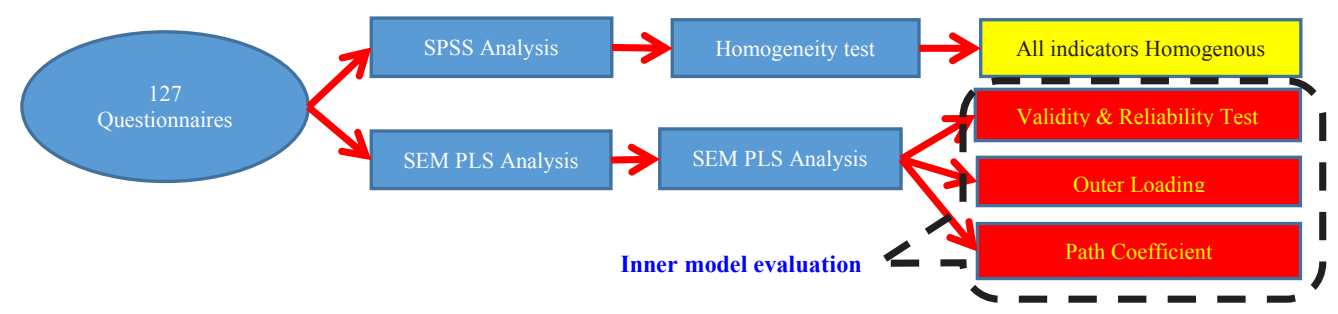

Fig. 2. Data Analysis

\section{Results}

The analysis was conducted in two stages, namely the study of collaboration variables model relationship with collaboration performance and continued with the report of the boundary 
indicator relationship model with the collaboration model. The results of the study that has been discussed presented in the form of the tabulation of the significance of Path coefficient and Outer loading of two models of relationship that is the model of performance and boundary spanners on the model, as follows:

Table 1. Influences ranking of collaboration model indicators to collaboration performance

\begin{tabular}{|c|l|r|}
\hline $\begin{array}{c}\text { Rank of } \\
\text { Influences }\end{array}$ & \multicolumn{1}{|c|}{ Collaboration Model Indicators } & $\begin{array}{c}\text { T Statistics } \\
(|\mathbf{O} / \mathbf{S T D E V}|)\end{array}$ \\
\hline 1 & M3.1.2<- Organizational Structure & 140.404 \\
\hline 2 & M3.4.2<- Basis of accountability and industry & 110.594 \\
\hline 3 & M3.1.1 <- Organizational Structure & 72.634 \\
\hline 4 & M1.3.3<- After the agreement & 57.960 \\
\hline 5 & M2.1.2<- Bringing the parties to collaborate & 57.203 \\
\hline
\end{tabular}

Table 2. Influences ranking of boundary spanners indicator to collaboration model

\begin{tabular}{|c|l|r|}
\hline $\begin{array}{c}\text { Rank of } \\
\text { Influences }\end{array}$ & \multicolumn{1}{|c|}{ Boundary Spanner Indicators } & $\begin{array}{c}\text { T Statistics } \\
(|\mathbf{O} / \mathbf{S T D E V}| \mathbf{)}\end{array}$ \\
\hline 1 & M4.7.1 <- Geographic Boundary Spanner & 138.479 \\
\hline 2 & M4.10.4.8<- Ethnic Culture Boundary spanner & 59.853 \\
\hline 3 & M4.7.2<- Geographic Boundary Spanner & 53.324 \\
\hline 4 & M4.1.1 <- Collaboration process/project Model & 40.957 \\
\hline 5 & M4.10.4.9<- Ethnic Culture Boundary spanner & 38.944 \\
\hline
\end{tabular}

Table 3. Relationship Ranking of collaboration model variables to collaboration performance

\begin{tabular}{|c|l|r|r|}
\hline $\begin{array}{c}\text { Rank of } \\
\text { Relationship }\end{array}$ & \multicolumn{1}{|c|}{ Variable Relationship } & \multicolumn{1}{|c|}{$\begin{array}{c}\text { Original } \\
\text { Sample (O) }\end{array}$} & $\begin{array}{c}\text { T Statistics } \\
\text { (|O/STDEV|) }\end{array}$ \\
\hline 1 & $\begin{array}{l}\text { After the agreement -> Cooperation in } \\
\text { the project }\end{array}$ & 0.551 & 7.421 \\
\hline 2 & $\begin{array}{l}\text { The best way to work -> Process/project } \\
\text { Collaboration model }\end{array}$ & 0.660 & 7.028 \\
\hline 3 & $\begin{array}{l}\text { After the agreement -> Bringing the } \\
\text { parties to collaborate }\end{array}$ & 0.481 & 6.932 \\
\hline 4 & $\begin{array}{l}\text { After agreement -> Collaborative } \\
\text { commitment of members }\end{array}$ & 0.738 & 6.920 \\
\hline 5 & $\begin{array}{l}\text { Find agreement -> Identify possible } \\
\text { obstacles }\end{array}$ & 0.501 & 6.627 \\
\hline 6 & $\begin{array}{l}\text { Process/project collaboration model -> } \\
\text { Collaboration performances }\end{array}$ & 0.403 & 3.897 \\
\hline
\end{tabular}

Tabel 4. Relationship Ranking of boundary spanners to collaboration model

\begin{tabular}{|c|l|r|r|}
\hline $\begin{array}{c}\text { Rank of } \\
\text { Relationship }\end{array}$ & \multicolumn{1}{|c|}{ Variable Relationship } & $\begin{array}{c}\text { Original } \\
\text { Sample (O) }\end{array}$ & $\begin{array}{c}\text { T Statistics } \\
\text { (|O/STDEV|) }\end{array}$ \\
\hline 1 & $\begin{array}{l}\text { Professional Boundary Spanners -> } \\
\text { Process/project Collaboration Model }\end{array}$ & 0.275 & 1.812 \\
\hline 2 & $\begin{array}{l}\text { Geographic Boundary Spanners -> } \\
\text { Process/project Collaboration Model }\end{array}$ & 0.241 & 1.751 \\
\hline 3 & $\begin{array}{l}\text { Stakeholder Boundary Spanners -> } \\
\text { Process/project Collaboration Model }\end{array}$ & 0.160 & 0.794 \\
\hline 4 & $\begin{array}{l}\text { Ethnic Culture Boundary spanners -> } \\
\text { Process/project Collaboration Model }\end{array}$ & 0.039 & 0.269 \\
\hline
\end{tabular}




\section{Discussions}

\subsection{Influences ranking of collaboration model indicators to collaboration performance}

Inter-organizational network (Organizational Structure), Performance Indicators Common goals (Basis of accountability and industry), Scattered across organizations (Organizational Structure), Conduct agreements (After agreement), and Explanation of cooperation methods (Carrying the parties collaborating) should get attention so that collaboration performance is going well because these are the most influential indicators with significant $\mathrm{T}$ statistical value.

\subsection{Influences ranking of boundary spanners indicators to collaboration model}

Provide shared workspace (Geographic boundary spanners), Equal feeling in the nation (Ethnic cultural boundary spanners), Provide shared social space (Geographic boundary), more structured of Project Indicators (Process collaboration model), and Equal feeling in the language (Ethnic cultural boundary) these are the most influential indicators.

\subsection{Relationship Ranking of collaboration model variables to collaboration performance variables}

Process/project collaboration model affects Collaboration performances with coefficient $=$ 0.403 and significant $\mathrm{T}$ statistic $=3.897>1.96$. This shows the significant effect of the relationship. Boundary number 1.96 shows the level of significance of the relationship between variables where if the value of statistic $\mathrm{T}$ is smaller than 1.96 then the relationship between these variables is not significant, on the contrary, if the value of T statistic is bigger than 1.96 then the relationship between these variables is Significant [28].

\subsection{Relationship Ranking of boundary spanners variables to collaboration model variables}

Relationship the professional boundary spanners indicators affect the process/project collaboration model on the design-build project is rejected even though it is related to the coefficient $=0.275$ but not significant $\mathrm{T}$ statistic $=1.812<1.96$ this indicates that the professional boundary spanners have not significantly influenced the collaboration model.

Relationship of geographical boundary spanners indicators affect the process/project collaboration model on the design-build project rejected even though there is a relationship with the coefficient $=0.241$ but not significant $\mathrm{T}$ statistic $=1.751<1.96$.

Relationship of stakeholder boundary spanner indicators affects the process/project collaboration model on design-build project rejected even though there is a correlation with coefficient $=0.160$ but not significant $\mathrm{T}$ statistic $=0.794<1.96$.

Relationship ethnic cultural boundary spanners indicator affect the process/project collaboration model on the design-build project is rejected even though there is a relationship with the coefficient $=0.039$ but not significant $\mathrm{T}$ statistic $=0.269<1.96$.

\section{Conclusions}

a. Critical success factors of project collaboration performance are as follows: Provide shared workspace (Geographic boundary spanners), equal feeling in the nation (Ethnic cultural boundary spanners), provide social space together (Geographic boundary 
spanners) Structured project implementation (Process/project collaboration model) and equal feelings in language (Ethnic cultural boundary spanners). Giving more attention to these factors on design-build projects is expected to improve collaboration performance.

b. The result of testing of process/project collaboration model has a significant influence on collaboration performance with path coefficient value $3.897>1.96$, then tested the impact and relationship between process/project collaboration model on boundary spanners indicators; geographic, stakeholders, professional and ethnic cultures. The results of testing of collaboration models with boundary spanners resulted in significant influence, especially on geographic and ethnic boundary spanners.

The authors would like to thank the financial support provided by Universitas Indonesia through the PITTA 2017 funding scheme under Grant number 861/UN2.R3.1/HKP.05.00/2017 Managed by the Directorate for Research and Public Services (DRPM) Universitas Indonesia.

\section{References}

1. Hu. W, International Conference on Information Management, Innovation Management and Industrial Engineering, (2008)

2. Howel. A. M, J. Lean. Constr., 2, 47 (2005)

3. G. Winch, J. Manage. Constr., (2010)

4. A. Kadefors, J. Project Manage., 22, 3, 175-82 (2004)

5. T. K. Gustavsson, O. S, J. IT. Const., 17, 520-534 (2012)

6. Ö. Wikforss, A. L, Itcon., 12, 337-345 (2007)

7. J. Runberger, Doctoral Dissertation, KTH School of Architecture (2012)

8. M. Bresnen, N. M, Const Manage. Econ., 18, 2, 229-37 (2000)

9. Eriksson. P. E, Const Manage. Econ., 28 (9), 905-917 (2010)

10. M Forman, S. L, Proceedings of the 6th Nordic Conference on Construction Economics and Organisation: Shaping the Construction/Society Nexus, 2 (2011)

11. J. Nyström, J. Constr. Manage. Econ., 23, 5, 473-481 (2005)

12. An-Shuen Nir, J.-F. D.-C. J. Business. Manage., 6 (19), 5927-5938 (2012)

13. Lise Lotte Homgreen, I. A, J. Cross-Cultural Manage., 339-356 (2013)

14. Erwin, M, 48-50 (2012)

15. Burgess, G. Encyclopedia of Conflict Resolution (1997)

16. L. Coser, The Functions of Social Conflict (1956)

17. M. Deutsch, The Resolution of Conflict: Constructive and Destructive Processes (1973)

18. Hansen M.T., N. N, MIT Sloan Management Review 46 (1), 22-30 (2004)

19. Roundtable, C. o. The Construction Users Roundtable. WP-1202 (2004)

20. G. Giesen, Creating Collaboration: A Process That Works (2007)

21. T. Xu, D. B, J. Project Manage., 21, 45-53 (2005)

22. Richman, H. S. The Power of Collaboration (2001)

23. Shawn Callahan, M. S, www.fullcire: http://www.anecdote.com (2006)

24. T. L. Foundation, The Johnson Center for Philanthropy and Nonprofit Leadership at Valley State University (2008)

25. Verganti, G. P, Harvard Business Review, 01-16 (2008)

26. J . Conner, Human Resource Planning, 26 (3) (2003)

27. T. K. Gustavsson, 7th Nordic Conference on Constr. Econ. Organisation (2013)

28. Hengky Latan, I. G (2012) 